\title{
Análise de conflitos socioambientais: atividades minerárias em comunidades rurais e Áreas de Proteção Ambiental (APA)
}

\section{Environmental Conflict Analysis: Mining Activities in Rural Communities and Environmental Protected Areas (APA)}

\author{
Daniel Trento NASCIMENTO* \\ Maria Augusta Almeida BURSZTYN**
}

\begin{abstract}
RESUMO
Este artigo busca analisar um conflito socioambiental que ocorre nas comunidades rurais de Santa Cruz e Esperança, no município de Içara, SC. O local do conflito também é uma área de proteção ambiental (APA) e a disputa se dá com uma grande mineradora de carvão que tenta se instalar no local. A análise do caso se deu com base na hipótese de que o acirramento dos conflitos socioambientais é um dos fatores determinantes para o fortalecimento das ações ambientais e formação de estruturas de governança ambiental local e, consequentemente, para institucionalização da gestão ambiental municipal. Para tanto, após a revisão teórica sobre conflitos socioambientais e mineração de carvão na região, foram identificados os principais atores e condicionantes que moldaram a disputa. Por fim, com base na análise do conflito, foi elaborado um mapeamento do mesmo e identificados os principais desdobramentos que corroboram a hipótese da pesquisa.
\end{abstract}

Palavras-chave: conflitos socioambientais; gestão ambiental; Sul catarinense.

\begin{abstract}
This article explores an environmental conflict that occurs in rural communities of Santa Cruz and Esperança in the city of Içara, Santa Catarina State. The site of the conflict is also an environmental protected area (APA) and the dispute is with a large coal mining company that is trying to be installed in the same area. The case analysis was developed on the assumption that the increasing of environmental conflicts is one of the determining factors for the strengthening of environmental actions and for the formation of local environmental governance structures, and, consequently, for the institutionalization of the municipal environmental management. Therefore, after a theoretical review of environmental conflicts and coal mining in the region, the main actors and conditions that shaped the dispute were identified. Finally, based on conflict analysis, a conflict mapping was designed and the main outcomes of the conflict that confirms the research hypothesis were identified.
\end{abstract}

Key-words: environmental conflicts; environmental management; southern Santa Catarina State.

\footnotetext{
"Doutor em Desenvolvimento Sustentável (UnB). Técnico do Ministério do Meio Ambiente (MMA). Email: danieltn@gmail.com

" Doutora em Ciências da Água - Gestão Ambiental (Universidade de Paris VI). Professora do Centro de Desenvolvimento Sustentável da Universidade de Brasília (CDS/UnB). Email: dute.cds@gmail.com
} 


\section{Apresentação}

Este artigo busca analisar um conflito socioambiental envolvendo a instalação de uma empresa mineradora de carvão numa comunidade rural instalada em uma Área de Proteção Ambiental (APA $\left.{ }^{1}\right)$. A hipótese norteadora da pesquisa se baseia na ideia de que o acirramento dos conflitos socioambientais é, em grande parte, um dos fatores determinantes para o fortalecimento de ações ambientais e para a formação de estruturas de governança local e, consequentemente, para a institucionalização da gestão ambiental local.

Esse pressuposto corrobora com a visão que Dahrendorf (1992) tem dos conflitos, ou seja, os conflitos são formas de evolução e aprendizado para corrigir o que, possivelmente, está errado e encontrar novos caminhos e possibilidades de desenvolvimento para a sociedade.

Nesse sentido, foi selecionado um caso no Sul catarinense, região de intensa atividade de exploração do carvão mineral e, como consequência, palco de vários casos de conflitos socioambientais envolvendo comunidades e empresas mineradoras.

O caso estudado ocorre nas comunidades agrícolas de Santa Cruz e Esperança, no município de Içara, SC. O conflito se dá entre agricultores familiares da região, estabelecidos no local há mais de 100 anos e com uma atividade agrícola bem sucedida, e uma grande mineradora, a Indústria Carbonífera Rio Deserto, com sede em Criciúma, SC (cidade vizinha) e proprietária de várias minas de carvão na região.

$\mathrm{O}$ conflito nasce quando a indústria consegue o direito de explorar o carvão no subsolo da área agrícola, que também é uma área de proteção ambiental (APA). Os agricultores, com medo dos impactos ambientais, econômicos, sociais e relacionados à saúde pública, se posicionam veementemente contra a atividade.

Dessa forma, por meio da análise de conflitos socioambientais, buscou-se identificar os principais atores e seus posicionamentos ao longo do processo, bem como as condicionantes que moldaram a disputa. Além disso, de forma a avançar nas análises e identificar elementos que corroboram a hipótese da pesquisa, foram identificados os desdobramentos do conflito.

Para o levantamento dos dados, foram realizadas pesquisas de campo na região nos meses de junho, julho e dezembro de 2008 e janeiro e julho de 2009. Foram feitas entrevistas abertas, não estruturadas, com atores-chave ${ }^{2}$ no processo envolvendo lideranças comunitárias, empresas mineradoras, políticos, técnicos e funcionários das respectivas prefeituras, órgãos ambientais, entre outros.

É importante registrar que durante a realização da pesquisa também foram visitadas na mesma região localidades com atividades de mineração de carvão, mas sem conflitos e com praticamente nenhum processo de fortalecimento da gestão ambiental em curso, diferentemente do que foi encontrado no caso selecionado, reforçando a hipótese da pesquisa.

\section{Conflitos socioambientais}

Os mecanismos de resolução de conflitos tiveram avanço com os gregos e romanos. Entretanto, naquela época, os conflitos eram frutos de disputas entre territórios, sendo que hoje a análise de conflitos se dá tanto no âmbito das relações diplomáticas e territoriais como em relações internas, regionais, locais e até individuais, sendo este último objeto de estudo da psicanálise.

Na sociedade moderna, os conflitos tendem a ser internos e a própria sociedade passa a criar e recriar espaços institucionalizados de decisão e resolução de conflitos. Röling (1966) tratou de analisar os conflitos pela importância da lei. Para ele, a função mais importante da lei é a prevenção de conflitos por conseguir impor respeito às suas regras. Entretanto, nem todos conflitos podem ser evitados; dessa forma, os conflitos que surgem, independente

\footnotetext{
${ }^{1}$ De acordo com a Lei do SNUC, n. ${ }^{\circ} 9.985$ de 2000, Área de Proteção Ambiental (APA) é considerada uma unidade de conservação de uso sustentável e seu objetivo é compatibilizar a conservação da natureza com o uso sustentável de parcela de seus recursos naturais. Conceitualmente, uma APA é uma área em geral extensa, com certo grau de ocupação humana, dotada de atributos abióticos, bióticos, estéticos ou culturais especialmente importantes para a qualidade de vida e o bem-estar das populações. Seus objetivos básicos são: proteger a diversidade biológica, disciplinar o processo de ocupação e assegurar a sustentabilidade do uso dos recursos naturais. ${ }^{2}$ Antônio Matiola (agricultor); José Baldissera (Agricultor); Egídeo Frasson (Agricultor); Alvino Budni (Agricultor); Joelson Machado (Agricultor); Evandro Della Bruna (Agricultor); Gilmar Axé (ambientalista); Wlaterney Réus (advogado); Ricardo Lino (Fundai); Giovanna Serafim Couto (MPF); Superintendência da FATMA regional Criciúma; Derlei De Lucca (professora); Felipe (jornalista jornal Agora); Lucas (jornal Agora); jornal Agora; Simone Guidi (advogada empresa Rio Deserto); Rosimeri Redivo (gerente da empresa Rio Deserto); Murialdo Gastaldon (Unesc).
} 
de sua natureza, também podem ser considerados conflitos legais e sua origem pode se dar de três formas: (a) aqueles que surgem de diferentes visões e interpretações das leis; (b) aqueles que surgem pelo não cumprimento da lei ou pelo confronto à lei vigente; e (c) quando as leis são mudadas de acordo com interesses e circunstâncias do grupo com o poder de aplicá-las.

Nas ciências sociais, vários autores abordaram conflitos. Para Durkheim (1999), que viveu entre 1858 e 1917, os conflitos e crises eram transitórios e faziam parte de um processo mais amplo, inerente à natureza reformista e evolutiva da sociedade. De acordo com seu pensamento, as crises e conflitos eram consequências da estrutura social em momentos de fraqueza e ausência de regras, leis e normas.

Um dos autores mais relevantes no tema dentro da sociologia é Simmel (1858-1918). Simmel foi um dos responsáveis pelo surgimento da sociologia alemã juntamente com Weber e Marx. Na visão de Simmel (1969), os conflitos são formas de interação social capazes de modificar grupos de interesse, unidades e organizações. $\mathrm{O}$ conflito existe como forma de resolver divergências adquirindo algum tipo de unidade, mesmo que para isso seja necessário anular uma das partes envolvidas. O conflito tem sempre um lado positivo e um lado negativo, mas ambos estão integrados, sendo possível apenas separá-los conceitualmente, mas nunca empiricamente.

A análise da teoria do conflito de Simmel juntamente com a teoria funcionalista foi feita pelo norte americano Lewis Coser (1913-2003). Seu trabalho focou nas funções do conflito social. Para Coser (1961), conflitos com outros grupos sociais aumentam a coesão interna e ajudam a definir a estrutura do grupo, bem como levam à formação de alianças. Os conflitos ajudam na função de comunicação, ou seja, contribuem para o esclarecimento dos posicionamentos dos atores. Se antes de um conflito não se sabe ao certo a posição e interesses diretos dos adversários, com o conflito tudo vem à tona.

Dos autores mais recentes, é válido citar Dahrendorf, discípulo de Karl Popper, sociólogo e filósofo alemão nascido em 1929 e que faleceu em 2009. Seu trabalho foca no conflito de classes da sociedade industrial e na transição para os movimentos sociais organizados. Para Dahrendorf(1992, p. 61), quando tratando do conceito de classes e conflitos, "a desigualdade e o poder continuam a ser fatores influentes que conduzem a interesses divergentes e ao confronto".

Diferentemente de Coser, Dahrendorf (1992) critica a explicação dos conflitos pela teoria funcionalista, que não enxerga o conflito como algo inerente ao sistema social, mas como uma distorção do mesmo. Para ele, a ideia de sistema integrado das funções sociais acaba levando à crença de existência de uma sociedade sem conflitos e isso pode ser perigoso, pois pode levar à anomia e ao consequente autoritarismo, pois com o uso da força pode-se impedir o surgimento de conflitos. De acordo com Dahrendorf, não existe certeza sobre todas as coisas e é justamente esta incerteza que faz surgir a divergência de opiniões e posicionamentos perante casos concretos. Por isso, na visão dele, os conflitos são formas de evolução e aprendizado para corrigir o que possivelmente estava errado e buscar novos caminhos para a sociedade.

Outra linha de estudo dos conflitos abrange o estudo da lógica da ação coletiva (OLSON, 1999) e a análise institucional dos Commom Pool Resources - CPR (OSTROM, 1990), que lidam com as disputas e conflitos por recursos e bens de interesse comum. $\mathrm{O}$ artigo mais emblemático dessa linha é o trabalho de Hardin (1968), The Tragedy of the Commons.

De acordo com Hess e Ostrom (2007), bens comuns são relacionados aos sistemas difíceis de limitar o acesso e o onde o uso do recurso por uma pessoa não impede o uso por outra pessoa como, por exemplo, no caso da informação disponível no mundo digital. Por outro lado, os bens naturais de uso comum são de certa forma abundantes, mas não infinitos, sendo assim importante e possível definir quem são seus usuários reconhecidos e também excluir o acesso a outros usuários com alto potencial de causar desequilíbrios sociais, ambientais ou econômicos.

Em sistemas de governança, onde é necessário decidir como os recursos serão alocados, alguns conflitos relacionados às políticas, regras e administração são bem susceptíveis de ocorrerem. Sistemas que ignoram essa possibilidade de conflito estão automaticamente aumentando a possibilidade dos mesmos ocorrerem e isto pode eventualmente resultar em problemas maiores. $\mathrm{O}$ estabelecimento de sistemas hierárquicos rígidos pode aumentar a velocidade das decisões, mas, ao mesmo tempo, pode ignorar os interesses de alguns dos participantes do processo e colocar em risco o próprio sistema. Dessa forma, é essencial elaborar uma estrutura de governança com ações voltadas aos diferentes graus de envolvimento dos atores de maneira a facilitar a descoberta rápida de conflitos e identificar formas efetivas de resolução dos impasses (OSTROM, 2008).

Dentro da perspectiva de estudo dos conflitos socioambientais, também é importante mencionar o movimento 
de justiça ambiental. Originado nos EUA na década de 1980, este movimento busca alertar para a situação recorrente de comunidades pobres em áreas de risco ambiental e social.

O conceito de justiça ambiental, de acordo com a Rede Brasileira de Justiça Ambiental (RBJA, 2009), busca denunciar a lógica que define os locais onde serão instalados os grandes empreendimentos de mineração, as barragens das hidrelétricas, a passagem de linhas de transmissão de eletricidade, de oleodutos e outras obras, como depósito de lixos tóxicos ou de resíduos químicos. A injustiça ambiental ocorre quando o desrespeito ao meio ambiente é acrescido pelo desprezo às populações mais pobres e vulneráveis.

A definição acima se confunde com a definição de ambientalismo ou ecologismo dos pobres, mas de acordo com Martinez-Alier (2007), o conceito inicial de justiça ambiental cunhado nos EUA está mais relacionado à sociologia ambiental e ao estudo das minorias do que à ética ambiental.

Martinez-Alier (2007) chama de ecologia dos pobres as mobilizações comunitárias e sociais de agricultores familiares e campesinos pelo direito de acesso comum aos recursos naturais contra atividades de alto impacto ambiental que podem restringir sua subsistência. É um movimento diferente do movimento ambientalista tradicional, pois tem na conservação do meio ambiente a manutenção das suas necessidades básicas como alimentação e abrigo.

A ecologia dos pobres tem a luta contra a pobreza como seu mote central e a conservação dos recursos naturais como um meio de sobrevivência. São grupos que, na busca pela manutenção de sua atividade tradicional, enfrentam grupos poderosos política e economicamente. Um dos exemplos mais emblemáticos da ecologia dos pobres citados por Martinez-Alier eram os "empates" liderados por Chico Mendes, no Acre, onde comunidades da floresta que dependiam da manutenção dos seringais para sobreviver enfrentavam os poderosos madeireiros.

De forma geral, os conflitos socioambientais são parecidos com os outros conflitos sociais existentes; entretanto, os conflitos socioambientais têm a característica de englobar coletividades em torno de bens difusos e, geralmente, com leis e instituições ainda incipientes ou por serem construídas (THEODORO, 2005).

\section{Análise de conflitos socioambientais}

A análise dos conflitos apresenta esquemas analíticos que ajudam na compreensão das ações dos atores, dos seus posicionamentos, da dinâmica e das relações cruciais inerentes ao processo de disputa. Não pretende solucionar os problemas, pois são muitas variáveis que os envolvem, mas busca apresentar elementos-chave e definidores dos mesmos de forma clara, possibilitando uma melhor tomada de decisão.

De acordo com Nascimento (2001, p. 95), os conflitos reúnem um conjunto de atores e posicionamentos que se articulam ou se opõem. Os atores movimentam-se e posicionam-se, mas nem sempre com discursos coerentes com suas ações. Nem sempre são perceptíveis em seus movimentos e isso torna a análise de conflitos difícil. Dentro dessa ideia, os atores de um conflito podem ser indivíduos, grupos sociais, organizações, coletividade e Estados e podem ocupar os seguintes posicionamentos perante o conflito:

a) promoção: dispostos a se movimentar com todos os seus recursos para que haja um determinado desfecho;

b) apoio: quando têm uma posição favorável a determinadas inciativas ou desfecho, mas não estão dispostos a se jogar com todas as suas forças no processo;

c) neutralidade: quando por alguma razão não têm ou não querem assumir posição;

d) oposição: quando se colocam contra determinadas iniciativas, mas não estão dispostos a utilizar todos seus recursos;

e) veto: quando utilizam todos os seus recursos possíveis para impedir que o conflito caminhe em um determinado sentido.

O campo do conflito é o espaço de movimento dos atores. Em relação ao objeto de disputa, este pode ser "material ou simbólico, divisível ou indivisível, laico ou profano, real ou irreal. Os objetos podem variar de natureza, mas são sempre bens ou recursos escassos, ou vistos como tais" (NASCIMENTO, 2001, p. 96).

A respeito do objeto de disputa, Nascimento (2001) ainda ressalta para o fato de que a percepção sobre o objeto é diferenciada entre os atores. Sua leitura, compreensão e valorização são distintas para cada um dos envolvidos.

Um conflito apresenta, de forma geral, três fases principais: preparação, embate e conclusão (NASCIMENTO, 2001). Outros autores apresentam um detalhamento maior inserindo as seguintes fases: preparação, anúncio, desenvolvimento, agudização, estagnação, institucionalização, negociação, acordo (pacto ou resolução). 
Sobre essa percepção diferenciada, Adams et al. (2003) colocam que é justamente quando os diferentes atores revelam suas interpretações e percepções sobre o objeto de disputa que o debate em torno de novas políticas e decisões se torna mais produtivo. Obviamente que isso não garante um resultado onde todos ganham, mas ao menos pode servir como um início de decisões pactuadas e consensuais.

Os conflitos socioambientais não são simples, pois os caminhos para a solução dependem, entre vários fatores, da percepção dos seus protagonistas. As políticas para melhorar a gestão geralmente assumem que os problemas são autoevidentes, mas, na realidade, uma consideração cuidadosa e transparente nas formas que os diferentes atores entendem e percebem os problemas é essencial para iniciar um diálogo efetivo (ADAMS et al., 2003).

Devido à complexidade dos conflitos, é importante não se perder a noção de que tais conflitos não são resolvidos por procedimentos binários: bem x mau, heróis x vilões, legal x ilegal, formal x informal (THEODORO, 2005).

Dentro dessa visão, a percepção sobre os problemas de uso dos recursos pode ser formada com base em três tipos de conhecimento: conhecimento do contexto empírico; conhecimento das leis, regras e instituições; e crenças, mitos, valores e ideias (ADAMS et al., 2003, p. 1916).

No que diz respeito aos tratamentos e formas de mediação dos conflitos, Theodoro (2005) coloca que os principais mecanismos que têm sido utilizados no Brasil, além dos meios jurisdicionais públicos, muitas vezes limitados, são: conciliação, arbitragem e mediação.

a) Conciliação: meio extrajudicial de tratamento dos conflitos onde as partes já se polarizaram sobre o objeto de disputa e há identificação clara do problema. Sua solução pode resultar em três hipóteses: a desistência de uma das partes, a submissão ou a transação negociada;

b) arbitragem: meio em que as partes escolhem um árbitro para resolver o conflito pautado por limites estabelecidos por uma cláusula arbitral e ao final as decisões ficam vinculadas a uma sentença arbitral;

c) mediação: é um meio de tratamento autocompositivo em que o mediador não decide, mas facilita o diálogo. O papel do mediador é explicitar os fatos que lhe foram narrados pelas partes, seus prós e contras, sem tomar partido ou apresentar uma solução definitiva. É um procedimento mais brando e que considera mais os aspectos legais envolvidos no conflito. Indicado apenas para crises menos intensas.

O caso do conflito na mineração é de sobreposição direta. As comunidades locais requerem o direito sobre suas terras e os mineradores estão interessados nos recursos naturais do subsolo sem considerar quem tem o controle da superfície, bem como os impactos que surgirão para estes (LITTLE, 2001).

$\mathrm{Na}$ maioria das vezes, os grupos que fazem as intervenções alterando o ambiente são os principais beneficiários econômicos de tal atividade e não são estes que arcam com os impactos negativos da exploração dos recursos naturais, ou seja, os grupos que não recebem os benefícios, são aqueles que ficam com os impactos gerados e os geradores dos impactos são os que ficam com os benefícios (LITTLE, 2001).

É justamente isso que ocorre no caso em análise. Em geral, os conflitos socioambientais mais difíceis tendem a acontecer onde há um choque entre diferentes sistemas produtivos. No caso analisado neste trabalho, os agricultores têm sua subsistência baseada numa relação direta com o ecossistema onde vivem, diferentemente dos sistemas fabris e industriais.

Nesta pesquisa, o conflito é visto como um elemento contribuinte para a evolução institucional para a melhor governança ambiental ${ }^{3}$ local e criação de instrumentos de gestão ambiental municipal. Considera-se que sem o conflito essa estrutura institucional levaria mais tempo para surgir ou mesmo não existiria.

\section{A mineração de carvão no Sul catarinense}

A região Sul catarinense passou por vários ciclos de desenvolvimento ao longo de sua história, tendo seu início no final do século XIX, com a vinda de imigrantes europeus, principalmente italianos, que tiveram a primeira base na região de Urussanga. No início do século XX, a região teve seu maior impulso econômico com o começo da exploração do carvão mineral e a consequente construção da estrada de ferro Dona Tereza Cristina, já na década de 1920.

\footnotetext{
${ }^{3}$ Governança ambiental diz respeito ao conjunto de processos regulatórios, mecanismos e organizações pelos quais atores políticos buscam influenciar as ações ambientais e seus resultados (LEMOS; AGRAWAL, 2006).
} 
Com as minas de carvão, as companhias mineradoras construíram as vilas operárias, que impactaram consideravelmente a aglomeração populacional no espaço da região. É interessante perceber que em algumas cidades, como Criciúma, as vilas operárias tiveram energia elétrica antes do centro da cidade. A região chegou a ter mais de cem minas em operação no início do século XX, todas de forma muito rudimentar e, como todas outras áreas, sem nenhuma preocupação com o meio ambiente (HÜLSE, 2008).

No período da Segunda Guerra Mundial, o carvão catarinense foi muito demandado internacionalmente, mesmo tendo baixa qualidade, pois a escassez no mercado internacional favorecia. Em outro período, na década de 1970, a crise do petróleo fez aumentar o interesse pelo carvão da região. Também nessa época, a exploração era muito desordenada e sem nenhuma preocupação ambiental (HÜLSE, 2008).

A lavagem do carvão com devolução direta nos cursos d'água e os rejeitos depositados a céu aberto contribuíram muito para a poluição de quase toda bacia hidrográfica da região (mais de $70 \%$ comprometida).

Em 1980, tendo em vista os impactos ambientais causados pela mineração em todo Sul catarinense, a região foi considerada, por intermédio do decreto federal n. ${ }^{\circ} 85.206 / 80$, como área crítica nacional para efeitos de controle da poluição e melhoria da qualidade ambiental.

Os impactos ambientais da exploração desordenada do minério estão presentes nas principais bacias hidrográficas da região, completamente poluídas, bem como nas muitas nascentes que desapareceram sob o patrocínio das empresas de mineração. Também o poder público pouco fez para evitar os danos, pois agia de forma omissa e inoperante (CORRÊA, 2002).

De acordo com estudos elaborados pela Agência de Cooperação Internacional do Japão (JICA, 1998), eram aproximadamente 4.700 hectares degradados. Atualmente existe um Termo de Compromisso de Ajustamento de Conduta (TAC) e está sendo constatado que existem mais áreas que o referido estudo não havia incluído, chegando próximo de 6.000 ha a área da degradação causada pelo carvão.

Hoje a mineração no Sul catarinense é feita por 10 indústrias, gerando um total de 4.000 empregos diretos. As empresas em atividade são as carboníferas Belluno, Catarinense, Criciúma, Metropolitana, Rio Deserto, Minageo, Siderópolis, Coperminas, Comin e Gabriela.

De acordo com Hülse (2008), todas possuem Sistemas de Gestão Ambiental (SGA) e a Rio Deserto possui
ISO 14.000 para algumas unidades. A principal utilização do carvão mineral hoje é na geração da energia elétrica produzida pela Tractebel, que administra a termoelétrica Jorge Lacerda (mais de $90 \%$ do carvão produzido na região é utilizado na geração de energia).

A participação do carvão mineral na matriz energética nacional é inferior a $2 \%$ e a contribuição brasileira mundialmente não representa $0,3 \%$ na produção mundial do carvão mineral. As reservas brasileiras são inexpressivas e de baixo aproveitamento, tanto para geração de energia como para fins siderúrgicos.

O carvão brasileiro das minas do sul tem altíssimos teores de cinza e enxofre, o que o torna de baixíssima qualidade. Sua combustão com as tecnologias atuais é de baixa eficiência energética e emite grande quantidade de óxido sulfuroso $\left(\mathrm{SO}_{2}\right)$ e de óxido nitroso $\left(\mathrm{NO}_{2}\right)$, que, em contato com a atmosfera, se transformam em ácido sulfúrico e ácido nítrico, causadores da chuva ácida (VIANNA, 2001).

Além disso, é importante considerar o fato de o carvão ser poluente tanto na extração e beneficiamento como no transporte e na sua queima. Emite dióxido de carbono, dióxido de nitrogênio, enxofre e destrói os solos, reduz a biodiversidade, polui os recursos hídricos e o ar. É um produto que consegue ser poluente em todas as etapas de sua cadeia produtiva.

\section{Conflitos entre comunidades rurais e mineradoras na região}

O conflito em análise não é o primeiro que ocorre na região envolvendo comunidades rurais e mineradoras de carvão. De acordo com Freitas (1998), em 1988, no município de Siderópolis, houve um conflito envolvendo a Companhia Siderúrgica Nacional (CSN) com moradores da localidade rural de Montanhão.

Em 1994, ocorreu um conflito entre a Companhia Carbonífera Belluno, que resolveu abrir uma mina numa área rural, também no Sul catarinense, o que acabou na mobilização de aproximadamente 200 agricultores que pressionaram a Câmara de Vereadores do município, resultando na transformação da área em uma APA.

No município de Urussanga, em 1995, de acordo com Catâneo (2009), a Associação Comunitária do Alto Rio Molha (Acarimo) conseguiu avanços contra o assoreamento dos rios e áreas degradadas pela mineração de carvão da mineradora Treviso. 
Em Criciúma, teve o caso do Morro Albino e Morro Estevão, ocorrido em 1996. Nessa localidade, os moradores conseguiram se articular para a criação de uma APA com o objetivo de impedir a instalação de mineradoras na localidade.

Em 1999, no município de Siderópolis, uma comunidade passou a protestar contra perturbações nas moradias e incômodos nas pessoas e animais devido à lavra iniciada na Mina Trevo, operada pela Indústria Carbonífera Rio Deserto. Os principais problemas, conforme relatam Ribeiro e Ferreira (2007), eram relacionados à fuga das águas superficiais devido ao rebaixamento do lençol freático, com consequente diminuição do nível da água em alguns córregos e poços da zona rural local. Além disso, a comunidade se queixava muito das vibrações sentidas com as detonações. Com base em negociações, a comunidade conseguiu alguns avanços.

De acordo com Ribeiro e Ferreira (2007), o papel exercido pela população local é de grande importância para o monitoramento e fiscalização das atividades da empresa, visto que um programa contínuo de monitoramento dos eventos de detonação de uma mina é inviável para os órgãos fiscalizadores devido à falta de pessoal, de equipamentos e de verbas para isso.

\section{Contextualização da área de estudo}

O município de Içara localiza-se no litoral Sul do Estado de Santa Catarina, nas coordenadas 28\%42'12" de latitude Sul e 49 $16^{\prime} 54^{\prime \prime}$ de longitude Oeste. Içara está a 10 $\mathrm{km}$ da cidade de Criciúma e a $190 \mathrm{~km}$ ao Sul da capital do Estado, Florianópolis. O município é pertencente à Associação dos Municípios da Região Carbonífera (AMREC) e faz parte da APA federal da Baleia Franca.

Sua população é de 54.070 habitantes (IBGE, 2007) e, por ser uma cidade litorânea, apresenta uma população flutuante de aproximadamente 150.000 habitantes no verão. Seu território ocupa uma área de $292.779 \mathrm{~km}^{2}$, com uma densidade populacional de 192,5 habitantes por $\mathrm{km}^{2}$.

No que diz respeito aos indicadores econômicos, Içara possui um PIB de R \$ 589.558 mil (IBGE, 2006), com renda per capita de R\$10.449,00 e um IDH de 0,78 (PNUD, 2000). O município tem diversas atividades econômicas, mas o destaque é para a apicultura, sendo um dos maiores produtores de mel do Brasil. São aproximadamente 20.000 colmeias produzindo até 600 toneladas de mel ao ano (IB-
GE, 2006). Na agricultura, o fumo é o principal produto, tendo também produção de feijão, milho, morango e arroz. $\mathrm{Na}$ indústria, destaca-se o setor de descartáveis plásticos, um dos maiores da América Latina (GOVERNO DO ESTADO DE SANTA CATARINA, 2009).

Há ocorrência de jazidas de carvão mineral no município e vários poços já foram explorados. Hoje, porém, todos já estão desativados, não havendo mais mineração, mas apenas áreas degradadas e outras em processo de recuperação. Também existem várias olarias e cerâmicas que exploram a argila em diversos pontos do município.

A cobertura vegetal do município tem somente $6 \%$ da área intacta (SOS MATA ATLÂNTICA, 2005). Os dados apontam para todo o município apenas 279,24 ha de mata virgem. $\mathrm{O}$ fragmento de maior relevância se localiza justamente na área de estudo.

\section{Área do conflito}

O conflito se dá nas localidades rurais de Santa Cruz e Esperança, onde vivem aproximadamente 300 famílias, totalizando mais de 1.000 pessoas. Há mais de 100 anos já existiam famílias no local trabalhando com agricultura familiar. Atualmente são 174 propriedades que tiram seu sustento exclusivamente da atividade agrícola, podendo manter um bom padrão de vida comparado a outros pequenos agricultores na região. $\mathrm{O}$ tamanho médio das propriedades é de 20 hectares. A maior parte das residências é de alvenaria, com acesso a telefone, internet, energia elétrica e a grande maioria tem um veículo para locomoção. Em suma, a agricultura familiar na área é bem sucedida e boa parte dos agricultores tem $2 .^{\circ}$ grau completo e alguns concluíram a faculdade (AGRICULTORES, 2009).

A renda familiar anual bruta na localidade é equivalente a $\mathrm{R} \$ 13.600 .000,00$. Os cultivos principais são o fumo, arroz e flores, além da apicultura e da criação de peixes e gado. De acordo com Matiola et al. (2003), existem remanescentes de Mata Atlântica bem preservados com uma grande diversidade de espécies da flora e fauna.

\section{Dinâmica cronológica do conflito}

Em um conflito socioambiental, as interações políticas são muitas e, consequentemente, as mudanças de posicionamento de alguns atores envolvidos no conflito não 


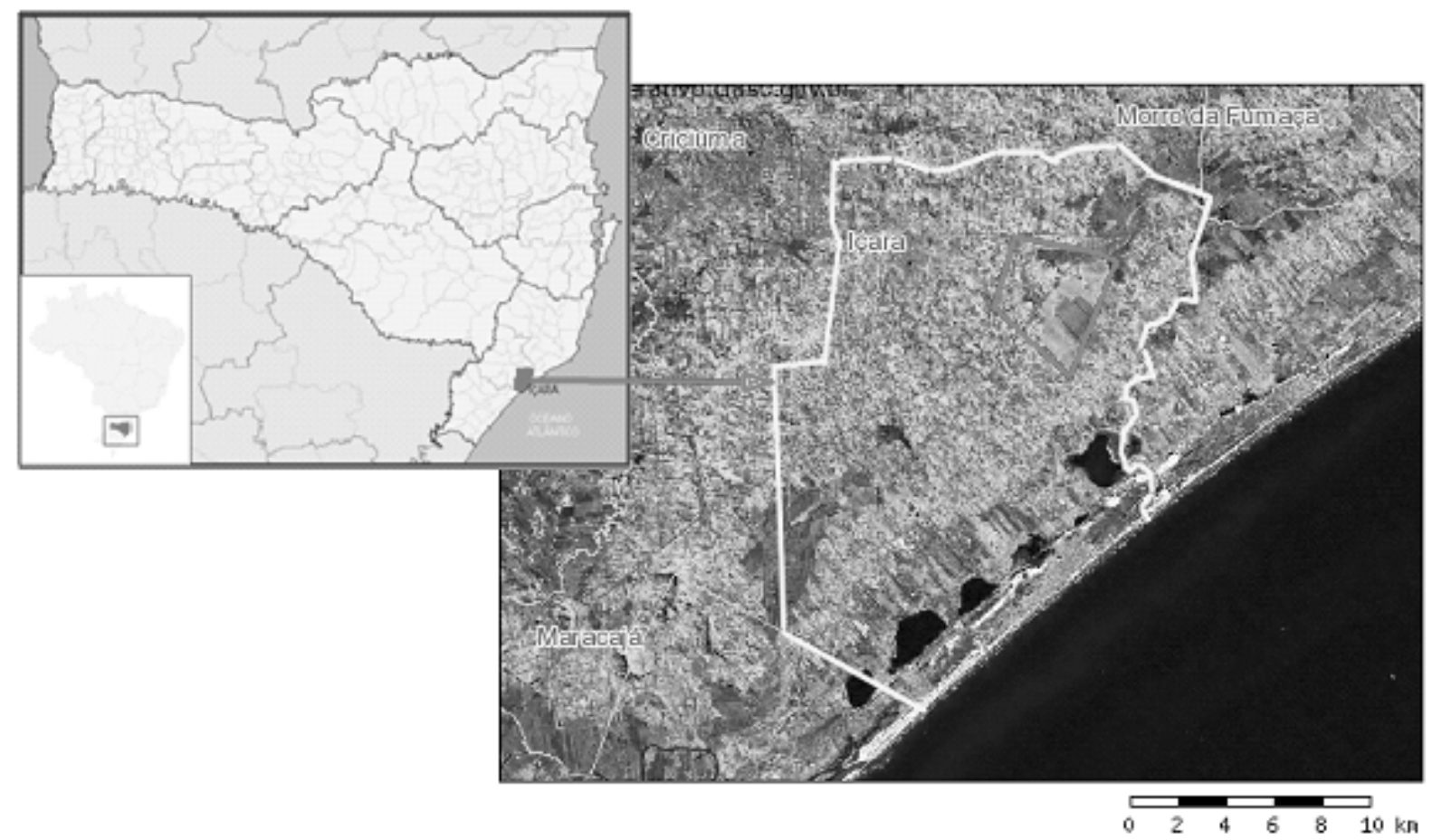

FIGURA 1 - IMAGEM DE SATÉLITE DO MUNICÍPIO DE IÇARA COM DESTAQUE PARA ÁREA DO CONFLITO. FONTE: CIASC (2009) E ABREU (2009).

são raras. Dessa forma, busca-se apresentar neste item as principais dinâmicas do conflito de forma cronológica, incluindo os posicionamentos dos diversos atores. De acordo com Little (2001), o tratamento adotado perante um conflito (confrontação, repressão, manipulação política, negociação/ mediação e diálogo/cooperação) pode variar de acordo com cada situação e momento. A seguir é apresentada uma descrição dos principais momentos da dinâmica do conflito numa ordem cronológica.

Em 2002 foi quando se falou publicamente sobre a possibilidade de instalação da mina em Içara, mas foi em 2003 que a comunidade local passou a tomar conhecimento, pois foi quando foi realizada a primeira audiência pública para tratar do assunto. A audiência contou com mais de 500 participantes, sendo a grande maioria mineiros levados pelo sindicato do setor (AXÉ, 2009; SANTOS, 2008). Logo após a audiência pública, a comunidade passou a se organizar, a realizar as primeiras reuniões locais e a formar grupos de trabalho para estudar o caso. De acordo com Axé (2009), a comunidade não teve tempo de analisar o estudo antes da audiência pública, mas em análises posteriores identificaram 45 irregularidades no documento.

Em 2004, os agricultores ingressaram com uma ação popular na Comarca de Içara solicitando a suspensão do licenciamento até que algumas questões não resolvidas no EIA/Rima fossem esclarecidas. Entretanto, o Juiz da Comarca extinguiu a ação alegando que objeto da ação, o licenciamento, ainda estava em curso e não poderia ser julgado. Entretanto, alguns meses depois, a licença prévia foi suspensa devido a várias irregularidades. A empresa teve de refazer o EIA/Rima e foram feitas alterações no projeto. Grande parte do processo de produção do carvão foi transferida para o município de Siderópolis, SC, ficando apenas a extração restrita à região.

Em novembro de 2004, a comunidade conseguiu o que pode ser considerado mais uma conquista, ou seja, foi aprovado um projeto de lei na Câmara de Vereadores transformando a área em disputa numa Área de Proteção Ambiental (APA). Por outro lado, assim que foi encerrada a eleição municipal, os vereadores apresentaram uma 
proposta de emenda na lei de criação da APA de forma a permitir atividade de mineração na área. Após isso, os agricultores protestaram contra o projeto de emenda com um "tratoraço" no centro da cidade e, em dezembro de 2004, o movimento dos agricultores entrou com uma ação direta de inconstitucionalidade (Adin) contra a alteração da lei da APA, baseado no fato de a alteração proposta ser menos restritiva que a Lei Federal.

Em fevereiro de 2005, foi expedida a Licença Ambiental Prévia (LAP: $n .{ }^{\circ}$ 005/05) mesmo tendo o EIA/Rima apontado alguns pontos que não garantiam a viabilidade do empreendimento. No entanto, em maio do mesmo ano, o Tribunal de Justiça de Santa Catarina (TJSC) concedeu medida liminar, suspendendo os efeitos da LAP e, assim, impedindo qualquer atividade relacionada à instalação na região do empreendimento. Em dezembro de 2005, a empresa apresentou um novo EIA/Rima, mas foi novamente rechaçado pela comunidade por não ter sido apresentado com antecedência para que pudessem analisá-lo. Por fim, em fevereiro de 2006, a Fatma concedeu a LAP e, em abril de 2006, concedeu a Licença Ambiental de Instalação (LAI).

Nesse meio tempo, corria no TJSC o processo de Adin impetrado pelos agricultores. No entanto, decorridos quase dois anos da ação, no dia 18 de fevereiro de 2008, foi iniciado o julgamento. Mais de 1.000 pessoas se posicionaram em frente ao Tribunal, em Florianópolis, capital do Estado, e o TJSC decidiu pela improcedência da Adin e concluiu que a lei de alteração da APA estava embasada legalmente.

O fato de a lei de alteração da APA estar embasada legalmente não implicava na autorização de instalação da mineradora, que ainda teria de cumprir os requisitos para receber a Licença Ambiental de Operação. Assim, em mais uma tentativa de frear o processo e impedir a instalação da mina, o movimento de agricultores articulou junto à sociedade do município um projeto de lei de iniciativa popular propondo a alteração do artigo que veio a permitir atividade de mineração na APA. No entanto, o projeto foi arquivado na Comissão de Constituição e Justiça da Câmara de Vereadores (CCJ).

Após isso, em março de 2008, após vários movimentos e ações de ambos os lados e acirramento do conflito, com a invasão e destruição da guarita dentro do terreno previsto para instalação da mina, o Procurador Federal, Darlan Dias, se apresentou para mediar e tentar uma conciliação e conseguiu chegar a um acordo formal onde havia 15 itens propostos pela comunidade. Destes 15 , apenas três não foram aceitos pela empresa e no dia 13 de abril, na iminên- cia de ser concluído o acordo, a comunidade retrocedeu e firmou posição contra a instalação da mina. $\mathrm{O}$ movimento não aceitou o acordo principalmente pelo fato de a caução em dinheiro referente a futuros danos ambientais ofertada pela empresa estar muito aquém do valor real dos imóveis.

No dia seguinte, a empresa Rio Deserto emitiu nota à imprensa local externando seu posicionamento frente ao fracasso da conciliação. Na sequência do imbróglio, a Rio Deserto conseguiu uma liminar para se instalar.

Em maio de 2008, a empresa conseguiu licença de instalação e construiu um galpão na área. No dia 20, um incêndio criminoso ocorreu nas instalações da mina 101 e a polícia iniciou perícia e investigação criminal para identificar e punir os culpados. De acordo com a assessoria de imprensa da empresa, os prejuízos se aproximaram de R\$ 300.000. No dia 28 de maio, um vídeo apócrifo acusando os agricultores do crime foi postado no site da internet youtube.

Em julho de 2008, organizações da sociedade civil do município se organizaram e passaram a apoiar com maior força o movimento dos agricultores. O que era chamado movimento pela vida passou então a ser chamado de Movimento Içara pela Vida (MIV). Entre as mais de 70 instituições que oficializaram sua participação estavam a Câmara de Dirigentes Lojistas de Içara (CDL), a Associação Comercial e Industrial de Içara (ACII) e a União das Associações Comunitárias de Içara (UACI).

Em outubro de 2008, ocorreram as eleições municipais e o candidato que se posicionou contrário à instalação da mina foi eleito. Já em abril de 2009, um dos últimos acontecimentos relacionados ao conflito registrados para esta pesquisa foi o fato de que o Ministério Público Federal conseguiu uma liminar obrigando a Fatma a conceder licenças somente com parecer técnico de vários profissionais (engenheiro químico industrial, agrimensor, civil, agrônomo, sanitarista, de minas, geólogo e um biólogo).

\section{Análise do conflito}

\section{Marco inicial e objeto de disputa}

O projeto da mina é de autoria da Indústria Carbonífera Rio Deserto, a mais antiga mineradora da região, criada em 1918, contando hoje com 15 unidades empregando 700 pessoas. A extração do carvão não é a única atividade da empresa, que atua em outros segmentos (RIO DESERTO, 2009). 
A unidade relacionada ao conflito é a unidade de extração 101. Este nome é referência à localização do projeto, às margens da rodovia BR-101. Entretanto, essa mudança de nome já é fruto do conflito. Anteriormente, o nome da unidade seria Mina Santa Cruz, em alusão ao nome da localidade, mas a comunidade solicitou a mudança. Também já foi chamada de Mina Esplanada, bem como de Mina Esperança.

Em 2003, o projeto foi orçado em R 12 milhões e prevê a extração de 360.000 toneladas de carvão vendável ao ano. O principal cliente é a Tractebel, empresa responsável pelas três unidades da usina termoelétrica Jorge Lacerda. Estima-se um tempo de vida útil de 14 anos e sua jazida possui 1.255 ha, com extração subterrânea em área de 900 hectares, sendo que na superfície a área operacional ocupará 4,7 ha (MOREIRA, 2006).

De acordo com os cálculos da empresa, com base em valores de 2002, a implantação da mina aumentará a renda per capita do município de Içara em $\mathrm{R} \$ 332,31$ ao ano e gerará uma massa salarial no valor de $\mathrm{R} \$ 4,2$ milhões anuais (MOREIRA, 2006). Da CFEM, seriam gerados aproximadamente R\$220.000,00 ao ano.

No que diz respeito ao ICMS, de acordo com Gastaldon (2009), com base nos dados fornecidos pela mineradora, o retorno anual de ICMS ficaria em R \$ 180.660,00. Esse valor, segundo ele, é um valor baixo, pois a receita municipal é de R \$ 60 milhões ao ano. Isso significa um acréscimo de pouco mais de $0,5 \%$ nas receitas municipais.

O marco inicial do conflito pode ser considerado a primeira audiência pública destinada a discutir o EIA/Rima para o licenciamento da mina. De acordo com Axé (2009), nenhum morador da região ficou sabendo da audiência pública com antecedência.

Como coloca Axé (2009), em agosto de 2003 a comunidade foi convidada para participar de uma reunião com os moradores das localidades de Esperança e Santa Cruz. Estavam presentes ao evento mineiros, mineradores, políticos, além de moradores da comunidade. Todos elogiavam o projeto e falavam dos benefícios que a implantação da mina traria para a localidade. Entretanto, um dos agricultores começou a questionar os impactos que as atividades causariam na água e na manutenção das atividades agrícolas. Gilmar Axé, ambientalista que estava na reunião, também mostrou descontentamento com o projeto.

Ao término da audiência, devido aos muitos questionamentos, os representantes da empresa mineradora convidaram Axé e outros agricultores a visitar algumas minas na região para melhor conhecer os novos procedimentos adotados. Ao mesmo tempo, os agricultores procuraram Axé para se organizarem e ver como poderiam conhecer melhor o projeto, os riscos e os caminhos que a comunidade poderia tomar para ter sua voz ouvida. Na semana seguinte, mais de 100 pessoas da comunidade se reuniram para tratar do assunto. Alguns vereadores e lideranças locais também participaram da reunião.

Um dos primeiros manifestos lançados pelos agricultores tinha vários argumentos contrários à implantação da mina, como se observa em Matiola et al. (2003): a boca da mina foi demarcada numa área de plantação de milho junto à BR-101; o depósito de pirita (rejeito) será numa área de plantação de arroz; a concessão da empresa é de 19.000 hectares, embora a empresa alegue que vai minerar "apenas" 900 hectares; desconfiança dos mineradores; e medo que ocorra na localidade o mesmo que ocorreu nas outras áreas mineradas, ou seja, alteração no lençol freático, diminuição das águas de superfície, contaminação dos rios, o cultivo do arroz ficará inviabilizado e as famílias terão de ir embora.

Fica evidente que o que está em jogo é a manutenção da área e da atividade agrícola na comunidade preservando a qualidade de vida atual versus a inserção de uma nova atividade econômica, com alto potencial de alteração da vida local, podendo gerar impactos nos recursos naturais, solo e subsolo, bem como alterar a estrutura social da localidade e provocar aumento do tráfego de veículos no local.

A própria empresa reconheceu mais tarde (2009) que uma das falhas foi não ter tido um maior diálogo com a população local antes de apresentar o projeto na primeira audiência pública (REDIVO, 2009).

A disputa se dá em função de impactos possíveis. De um lado, a empresa esforça-se para mostrar à comunidade que a mineração de hoje é diferente da que ocorria décadas atrás, quando boa parte da região foi impactada, incluindo fauna, flora, recursos hídricos e a sociedade em geral, com problemas de saúde. E, por outro lado, a comunidade teme impactos variados oriundos da atividade mineira que ocorreu e ainda ocorre em algumas minas na região. Percebe-se que o passado impactante da exploração de carvão na região ainda está bem presente no imaginário da população local.

De acordo com os agricultores (2009), o principal objeto de disputa é a água, pois, com a mineração a 30 metros de profundidade, o lençol freático corre sérios riscos de ser contaminado, prejudicando toda atividade agrícola na região.

Além disso, como argumenta Luiz (2004), outro problema da exploração na área é a sua proximidade com o mar e o consequente risco das águas do lençol marinho 
invadirem o espaço antes ocupado pela água doce durante o processo de bombeamento da água das galerias. Isso provocaria salinização dos rios e nascentes. Entretanto, na visão de Redivo (2009), a água será 100\% tratada e a região possui uma espécie de argila selante, o que impede a mistura da água subterrânea com a água da superfície. São posições conflitantes como estas que ajudam a agravar o conflito.

\section{Natureza e abrangência do conflito}

Como já se pode perceber, este conflito é de natureza econômica, social e ambiental: (a) econômica, pelo interesse da exploração da atividade de mineração e pela manutenção da atividade econômica da comunidade, a agricultura; (b) social, pelo envolvimento de toda comunidade, não só da localidade, mas também de toda a sociedade civil do município, bem como da região; (c) ambiental, pela evidente confrontação entre exploração de carvão dentro de uma APA, bem como outras questões que afloraram durante o conflito, como o maior cuidado que os próprios agricultores devem ter com o meio ambiente durante suas práticas agrícolas. Também existiram impactos na vida política do município, visto que o resultado da eleição municipal sofreu forte influência em virtude de posicionamentos favoráveis e contrários à mina.

O conflito que iniciou com a mobilização local rapidamente envolveu comunidades vizinhas e toda a cidade. Ao longo do conflito, várias questões foram decididas na capital do Estado (TJSC) e contaram com ampla cobertura da mídia estadual, ampliando o caráter do conflito de local para regional.

Identificação dos atores: interesses, posicionamento e identificação das cotas de poder $^{4}$ (formal e informal) de cada grupo 5

\section{Contrários à instalação da mina:}

a) Agricultores - Atores principais com poder informal de mobilização dos agricultores e da própria sociedade local. Muito embora o movimento começasse pequeno, em razão dos vários eventos, como os "tratoraços", hoje é uma força política e social respeitada não só no município, como em toda região;

b) Associações comerciais, industriais e terceiro setor do município - representação formal da classe. Forte influência na sociedade devido à sua representatividade e pluralidade na composição, que conta com mais de 70 instituições da sociedade civil;

c) Ambientalistas e representantes das universidades - baixo poder de expressão, mas com força junto aos membros do movimento devido ao aporte técnico e intelectual;

d) Políticos contrários à instalação da mina - expressão política formal pelos cargos que ocupavam e ocupam e informal por exercerem liderança em alguns bairros e setores da sociedade local;

e) Advogado - poder de representar legalmente as demandas do movimento com forte poder de influência, visto que elaborava os pareceres jurídicos que têm traçado o rumo do movimento. Informalmente também exerce sua influência pelo conhecimento de causa e da própria sociedade local;

f) MIV - movimento social que ganhou força e representatividade regional.

g) Imprensa local $\left(\right.$ marginal $\left.^{6}\right)$-Apenas um jornal de circulação local e um canal de TV davam espaços iguais tanto para a empresa como para a comunidade. Entretanto, ao longo do conflito, o canal de TV (Canal 19) foi comprado por um grupo ligado à mineradora e acabou com o espaço de discussão.

\section{Pró-mineradora:}

a) Empresa Rio Deserto - Forte influência política local, regional e até nacional. Apoia praticamente todos os meios de comunicação da região;

b) Departamento Nacional de Produção Mineral (DNPM) - Poder formal por ser uma instituição

\footnotetext{
${ }^{4}$ Em seu significado mais geral, poder significa a capacidade ou a possibilidade de agir, de produzir efeitos, de influenciar tanto indivíduos e grupos humanos como fenômenos (adaptado de BOBBIO, 2004, p. 933).

${ }^{5}$ Informações coletadas nas pesquisas de campo realizadas pelo pesquisador em junho, julho e dezembro de 2008 e janeiro e julho de 2009 .

${ }^{6}$ Utiliza-se aqui a expressão marginal apenas para diferenciar dos veículos com maior poder econômico e abrangência na sociedade local.
} 
federal dedicada à pesquisa e produção mineral e tem o interesse no aumento da atividade mineraria;

c) Políticos pró-instalação da mina - Poder de influência formal e local devido ao cargo ao qual ocupam e forte influência informal em todas as esferas da administração pública (federal, estadual e municipal), visto que a mineradora possui boa relação com deputados estaduais, federais e até senadores;

d) Sindicato da Indústria de Extração de Carvão do Estado de Santa Catarina (Siecesc) - Forte influência regional e nacional, com moderada força local devido à ausência de mineração no município.

e) Sindicato dos Mineiros - Forte influência na região, tendo sempre peso nas eleições para deputados e fraco no município de Içara devido à ausência de mineração no município;

f) Imprensa local (central) - Jornais e canais de comunicação (TV e rádio) que recebem patrocínio da Empresa Rio Deserto (interessada na questão). Influência moderada na formação de opinião regional, visto que os leitores, na maioria das vezes, já identificam os canais como porta-vozes de alguns setores.

\section{Órgãos ambientais:}

À primeira vista, o posicionamento dos órgãos ambientais (Ibama, Fatma, Fundai) tende a ser em prol da APA, visto que esta foi criada com o fim de proteger uma determinada área considerada importante ambiental e socialmente. Entretanto, por diversos fatores, o posicionamento de alguns dos órgãos em questão variou de neutralidade para oposição ao conflito, como se observa mais detalhadamente na sequência.

a) Fatma: Poder formal relevante, pois é o órgão responsável pela emissão da licença ambiental. Concedeu todas as licenças. Como se pode observar no comentário de Gastaldon (2009), existe muita contestação quanto à atuação do órgão na região: "A Fatma, que é estadual, pouco resolve e a todo instante está envolvida em escândalo por dar licenças ambientais fora da lei. É uma instituição que, apesar do esforço de seu corpo técnico, tem baixíssima credibilidade. No município temos a Fundai, que foi criada faz poucos anos. Nossa preocupação é evitar que a Fundai se transforme no que é a Fatma hoje".

b) Fundai: Poder formal moderado, visto que a decisão final sempre coube à Fatma; entretanto, teve forte influência ao expedir a anuência municipal para a atividade. Expediu o alvará que condicionava a licença.

\section{Mediadores $^{7}$ :}

Muito embora o posicionamento desses órgãos deva ser de neutralidade, na prática nem sempre isto ocorre. Mesmo que embasada por lei, a tomada de decisão favorável a uma ou outra parte acaba fazendo com que os chamados mediadores tomem um posicionamento no conflito. É justamente este posicionamento que se tenta descrever nas linhas que seguem.

a) Ministério Público Federal (MPF) - Poder formal expressivo e adquiriu considerável legitimidade. Para os agricultores, o Procurador tem buscado garantir algumas conquistas para a comunidade. Posição de mediador. Tentou conduzir vários acordos. É visto pela empresa com uma atuação imparcial e coerente, buscando sempre privilegiar o debate e o consenso. Já os agricultores o percebem como favorável à instalação da mina, mas procurando minimizar os impactos para a comunidade e o ambiente.

b) Tribunal de Justiça de Santa Catarina (TJSC) Poder formal nas decisões em que foi acionado. Participou do processo na votação da validade da Adin e deu parecer favorável à mineradora.

\footnotetext{
${ }^{7}$ A escolha do termo mediador para estes órgãos se deu pelo fato de não terem interesse explícito no conflito, pois foram acionados pelos trâmites judiciais e passaram a agir dentro do papel que lhes é cabido. Conforme já visto neste trabalho, com base em Theodoro (2005), o papel do mediador é explicitar os fatos que lhe foram narrados pelas partes, seus prós e contras, sem tomar partido ou apresentar uma solução definitiva. Entretanto, neste caso, os mediadores tomam decisões, pois são acionados para dirimir problemas de interpretação da lei per se, mas na ausência de qualquer outra forma parecida com mediador, conciliador ou árbitro, resolveu-se adotar este termo para designar os atores em questão.
} 


\section{Resumo do conflito}

Com base na matriz de análise de conflito de Theodoro (2005), na sequência é apresentado um resumo do conflito analisado:

a) natureza do conflito: econômica, social e ambiental;

b) objeto de disputa: recursos naturais. Minério por parte da empresa e água e serviços ambientais por parte da comunidade. Também está em jogo a manutenção da qualidade de vida e da agricultura familiar;

c) campo do conflito: local e regional;

d) atores principais: Mineradora; Siecesc; Sindicato dos Mineiros; Comunidade de Agricultores; MIV; Fatma; FUNDAI; MPF

Atualmente o conflito persiste. A empresa está se instalando no local e aguardando a licença de operação. Ao mesmo tempo, o movimento segue mobilizado buscando as alternativas jurídicas cabíveis. $\mathrm{O}$ advogado do movimento assumiu a Procuradoria do Município e posicionou-se contra a instalação da mina.

Em suma, existe uma situação onde o poder executivo é contrário à instalação da mina e o legislativo é favorável. Como se pode observar no comentário de Gastaldon (2009): "Na Câmara existe a bancada 'mineirista'. O poder financeiro da mina é muito grande. O único declaradamente a favor do meio ambiente é o Ver. Diego Vitorassi (PDT)".

Como complemento, de forma a apresentar uma síntese da dinâmica do conflito, foi elaborado um mapeamento geral e as interações mais marcantes ao longo do processo. Como o conflito ainda não se encerrou, também se procurou fazer um exercício para traçar os possíveis cenários, como se observa na Figura 2.

\section{Desdobramentos do conflito}

Neste tópico busca-se identificar os desdobramentos institucionais do conflito mais importantes e significativos. Tendo em vista a definição de instituição tomada por base neste estudo (OSTROM, 1990; NORTH, 1990; BAREMBLITT, 1996), de que instituições são leis, regulamentos, condutas, práticas costumeiras e reconhecimento social das estruturas que garantem a efetividade das condutas, abaixo são apresentados os desdobramentos do conflito que ajudam a corroborar com a hipótese levantada no início da pesquisa, qual seja, de que os conflitos socioambientais contribuem para a evolução institucional.

A-Práticas e processos revistos: (a) $\mathrm{O}$ processo de licenciamento foi revisto diversas vezes pela comunidade, professores e ambientalistas que apoiam o movimento. (b) $\mathrm{Na}$ localidade também existe extração de argila. Antes do conflito, a grande maioria estava em situação irregular. Entretanto, como a localidade passou a ter maior exposição com o conflito, os moradores começaram a se conscientizar dos danos ambientais e denunciar a extração ilegal e as empresas legalizadas passaram a corrigir suas práticas. (c) Os próprios agricultores modificaram suas práticas, diminuindo a aplicação de agrotóxicos. É consenso entre eles que existe maior conscientização ambiental.

B - Leis, normas, acordos e regulamentos: (a) Uma das grandes conquistas do movimento foi conseguir aprovar a lei que criou a Área de Proteção Ambiental. Ainda é preciso implementar seu conselho gestor, mas a APA foi criada. (b) Após uma alteração na Lei da APA para permitir atividade de mineração, desde que com licença ambiental, a comunidade tentou alterar novamente e conseguiu mais de 4.600 assinaturas de eleitores do município e enviou para a Câmara Municipal um projeto de lei de iniciativa popular. Muito embora o projeto tenha sido arquivado pela CCJ, é importante reconhecer o avanço que foi a proposição do projeto. (c) Ministério Público Federal conseguiu liminar obrigando a Fatma a conceder licenças somente com parecer técnico de vários profissionais (engenheiro químico industrial, agrimensor, civil, agrônomo, sanitarista, de minas, geólogo e um biólogo). O MPF solicitou suspensão da licença prévia, visto que todo o estudo do EIA/Rima não estava concluído quando da emissão da LAP. (d) Após reiterados conflitos, o MPF foi o responsável por iniciar um espaço de diálogo entre as partes e conseguiu intermediar um acordo inédito no setor com 15 itens. Entretanto, a comunidade rejeitou o acordo nos finais da negociação, mas o espaço de diálogo e as propostas aceitas e acatadas pela empresa podem ser considerados avanços no setor. A empresa mudou a localização, se comprometeu a não minerar no subsolo das propriedades, bem como alterou o nome da mina. (e) Suspensão da LAI e modificação do projeto. Com a pressão da comunidade e as sucessivas reuniões, a comunidade conseguiu alterar boa parte do projeto, como a mudança do local de beneficiamento do carvão, que a partir de então deixaria de ser feito na comunidade, bem como a localização da entrada da mina foi alterada e o transporte não seria mais feito pelo interior do bairro, mas 


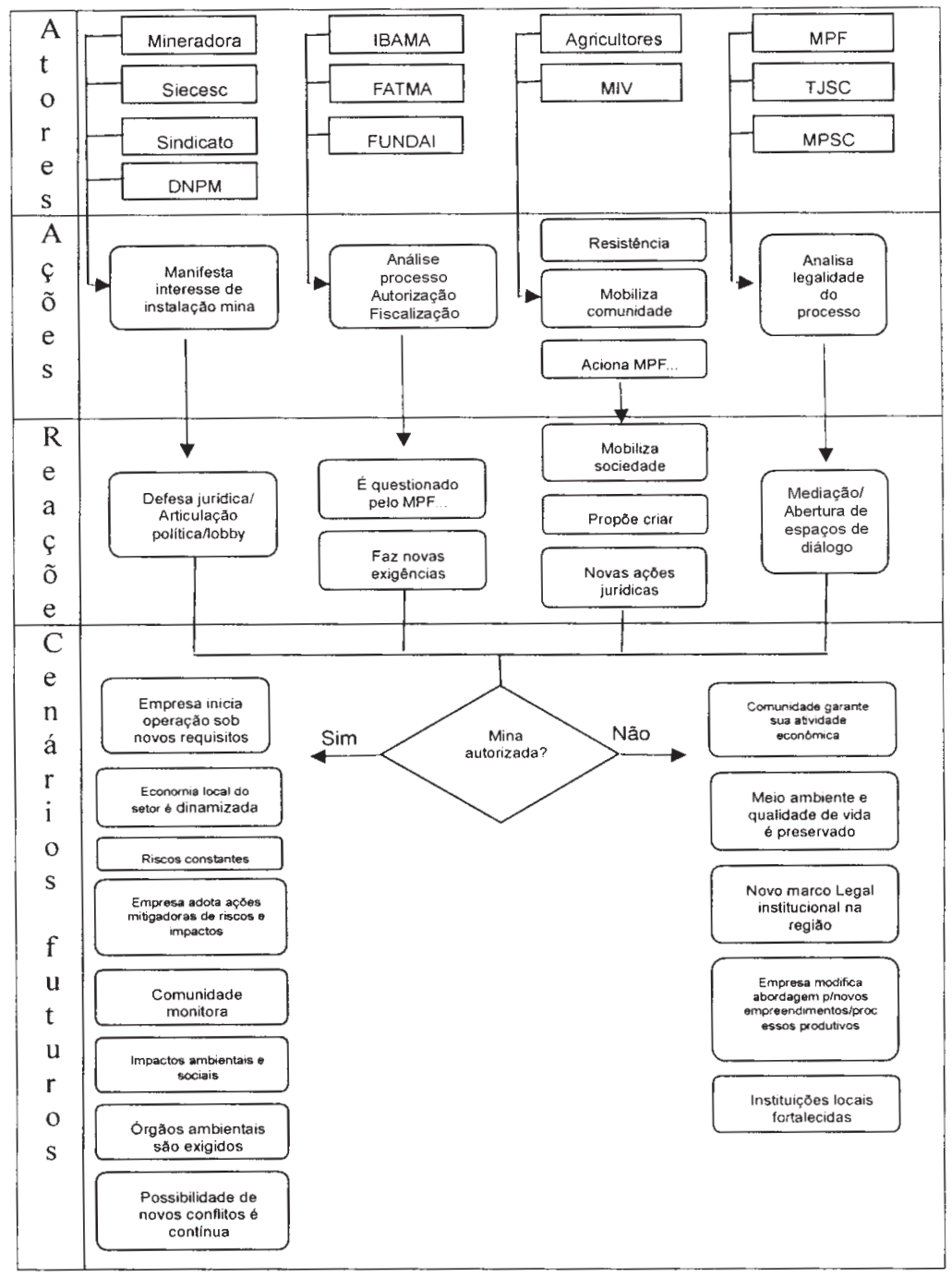

FIGURA 2 - MAPEAMENTO DO CONFLITO E CENÁRIOS FUTUROS. FONTE: ELABORAÇÃO PRÓPRIA, 2009.

pela BR-101. O lavador do carvão não seria mais instalado no local, assim como o rejeito (pirita) não seria depositado no local. (g) Conselho Gestor da APA: com a criação da APA, a Fundai trabalhou para a formalização do Conselho Gestor da mesma, o que teria sido também um avanço, pois o Conselho tinha uma composição paritária (LINO, 2008);

C-Conquistas sociais e aprendizado: (a) A criação do movimento de resistência à instalação da mina e seu reconhecimento e fortalecimento junto à sociedade local e regional. O MIV é composto por mais de 70 entidades da sociedade civil organizada do município. No início do imbróglio, o posicionamento "do centro" da cidade era favorável à mina, desconhecia as implicações do conflito; mas, após as manifestações, eventos e "tratoraços" organizados pelos agricultores, os dois lados do caso começaram a ser expostos para a sociedade. De acordo com Matiola 
(2009), no início eram tratados como quatro colonos desequilibrados que não sabiam o que era desenvolvimento. Com o passar do tempo e o conhecimento da situação, boa parte da sociedade civil organizada do município passou a apoiar o movimento. (b) $\mathrm{O}$ aprendizado social e a troca de experiências e informações com outras localidades em situações parecidas. Tanto a comunidade de Santa Cruz, no início de sua mobilização, foi aprender com a comunidade do Morro Albino, em Criciúma, que já tinha passado por um processo parecido, como algumas comunidades passaram a visitar os agricultores do bairro Santa Cruz em busca de informações. É o caso da comunidade de São Roque, que já procurou o movimento, pois existe uma mineradora em vias de instalação no bairro. (c) A comunidade de agricultores considera que os seis anos de luta já significam uma vitória, pois conseguiram atrasar o início das atividades. (d) Uma das grandes conquistas foi a conscientização sobre a força que a comunidade tem quando se mobiliza em prol de objetivos comuns. O empoderamento da comunidade nesse processo é algo reconhecido como uma das conquistas e avanços.

D - Desdobramentos políticos: (a) O resultado das eleições majoritárias no pleito de 2008 pode ser atribuído ao posicionamento dos candidatos favoráveis ou contrários à mina. $\mathrm{O}$ candidato que apoiou a comunidade foi eleito. (b) Conscientização também dos políticos que viram que a questão ambiental é sensível e não pode ser ignorada, principalmente quando relaciona população e meio ambiente. (c) Depois do conflito, conforme alguns relatos (MATIOLA, 2009; REUS, 2009, AXÉ, 2009) as mineradoras da região, muito embora ainda tenham muito a melhorar, já não são mais as mesmas. Até hoje, tirando o caso dos Morros Albino e Estevão, as mineradoras faziam um EIA/Rima inconsistente e o mesmo era aprovado sem dificuldades pelo órgão licenciador e pelas comunidades sem quase nenhuma contestação. Hoje isso tem mudado tanto por parte das comunidades, que passaram a estar mais atentas, como por parte das mineradoras, que passaram a adotar uma abordagem mais diplomática e menos autoritária.

\section{Considerações finais}

Este caso apresenta a situação de um conflito socioambiental que colocou boa parte de um município contra a instalação de uma mina de carvão. Legalmente isso é possível, pois cabe à União expedir o direito de exploração mineral. Entretanto, os impactos gerados pela exploração do carvão são regulados pelo órgão ambiental do estado (Fatma), que é o responsável pelo licenciamento do empreendimento.

Com os desdobramentos do conflito, ficou evidente que a Prefeitura era contra a instalação da mina, muito embora a Câmara de Vereadores se posicionou de forma favorável à instalação em vários momentos do conflito. Diante desse imbróglio, é possível tirar várias lições para a governança ambiental local e a institucionalização da gestão ambiental municipal.

Fica claro que grande parte das forças políticas e econômicas regionais é favorável ao setor de mineração. Como o órgão responsável pela licença é estadual e não municipal, percebe-se que o que ainda predomina na decisão é a manutenção das estruturas políticas e econômicas.

Com base em Ibama (2006), para que se alcance maior efetividade na gestão ambiental local, a definição de mecanismos que dificultem a alteração dos objetivos e diretrizes gerais da Política Municipal de Meio Ambiente e do Plano Diretor junto à Câmara de Vereadores é primordial, de forma a evitar ações oportunistas.

Tendo em vista que o órgão ambiental estadual concedeu a licença, este conflito traz para debate o princípio da precaução. Se em toda região o impacto ambiental e de saúde pública causado pela exploração do carvão é notório e está bem presente no imaginário da população, será que essa questão não deveria ser mais discutida com toda a sociedade visando minimizar os riscos ambientais e identificar alternativas mais sustentáveis para o desenvolvimento da região?

Além disso, considerando os dispositivos legais existentes, a licença pode ser questionada, pois, de acordo com o Artigo 19 da Resolução 237/97 do Conama, o órgão ambiental, mediante decisão motivada, poderá suspender ou cancelar uma licença expedida, quando ocorrer omissão ou falsa descrição de informações relevantes que subsidiaram a expedição da licença, bem como quando houver superveniência de graves riscos ambientais e de saúde.

Conforme dados da Munic (IBGE, 2008), o município de Içara tem conselho de meio ambiente deliberativo, mas, na realidade, durante todo o conflito ele esteve ausente. Fica claro que é fundamental a descentralização com participação e, em muitos casos, também com poder de veto, caso contrário as decisões do conselho serão sempre limitadas.

Outro fator importante a ser ressaltado no conflito em questão é o fato de a comunidade ter um bom poder aquisitivo e uma boa qualidade de vida. Isso faz com que os argu- 
mentos em prol da mineração sejam minimizados, pois os empregos não são tão sedutores como em localidades mais carentes. De acordo com o então presidente do Sindicato dos Mineiros, João Paulo Serafim, de cada emprego direto gerado na mina, mais oito serão gerados indiretamente, ou seja, se serão gerados 84 empregos diretos, o total de empregos (diretos e indiretos) será 656 (AGORA, 2008).

Entretanto, vivem da agricultura na comunidade mais de 300 famílias, ou seja, mais de 1.000 moradores. Dessa forma, emprego por emprego, a agricultura gera mais, sem contar com os empregos informais no período de colheita e a continuidade da atividade que já é centenária na localidade. Vale lembrar ainda o fato de existirem famílias com mais de 100 anos vivendo da agricultura na região. Sabe-se que a mina terá uma vida útil de 14 anos; assim, numa perspectiva de longo prazo, fica nítida a dificuldade da mineradora de convencer os agricultores dos benefícios do empreendimento para a comunidade local - que conhece bem os impactos potenciais e duvida dos resultados positivos argumentados pela mineradora.

Outro fator interessante são as várias acusações e suspeitas de relações não tão transparentes entre as empresas mineradoras e os órgãos fiscalizadores. Questões como estas levam à reflexão acerca dos fatores histórico-culturais brasileiros - como a corrupção, o clientelismo e o patrimonialismo - e ajudam a explicar algumas das barreiras para uma maior eficiência da gestão pública municipal.

Muito embora o conflito analisado ainda persista, este caso mostrou a importância da mobilização da comunidade envolvida em áreas de risco ambiental na luta pela garantia de seu direito constitucional de um meio ambiente equilibrado, essencial à sadia qualidade de vida, sendo fundamental defendê-lo e preservá-lo para as presentes e futuras gerações.

Um fato relevante verificado foi a importância que têm as prefeituras municipais na emissão de licenças am- bientais, sejam elas de competência do Estado ou da União, pois o município necessita emitir uma declaração de anuência ou alvará. Assim, percebe-se que o município não é tão impotente como se pensa em matéria de licenciamento de grandes empreendimentos.

Por outro lado, é importante registrar que a criação da APA foi um instrumento importante; entretanto, percebeu-se que o foco sempre foi impedir a continuidade das atividades da mineradora. Criou-se a APA, mas pouco foi feito para implementá-la, com comitê gestor atuante, plano de manejo, diretrizes de uso do solo, entre outros instrumentos.

Neste ponto, é válido resgatar Martinez-Alier (2007), que diferencia este tipo de movimento do movimento ambientalista tradicional, pois trata de mobilizações comunitárias com o objetivo principal de lutar pelo direito de acesso aos recursos naturais contra atividades de alto impacto ambiental que possam restringir sua subsistência ou seu modo tradicional de vida.

Enfim, percebeu-se que os momentos onde mais se avançou foram quando houve diálogo, mesmo que intermediado pelo MPF, como pode ser visto nos termos dos acordos celebrados entre as partes. Esta constatação corrobora com a visão de Ostrom (1990) de que, quando existe diálogo, a probabilidade de surgimento de novas instituições é maior.

Muito embora se compreenda que não é possível generalizar as lições do caso analisado para todos os conflitos, este caso evidenciou que conflitos socioambientais, que muitas vezes duram anos, podem ser decisivos e contribuir de forma significativa para o fortalecimento de ações ambientais e para a institucionalização da gestão ambiental. Como se observou, estruturas de governança, bem como novas leis e normas foram surgindo e fortalecendo o processo de discussão, favorecendo a institucionalização da gestão ambiental que antes não existia ou era frágil. 


\section{Referências}

ABREU, R. L. Mapa do Estado de Santa Catarina. Disponível em: <http://pt.wikipedia.org/wiki/Ficheiro:SantaCatarina_MesoMicroMunicip.svg>. Acesso em: 07 jul. 2009.

ADAMS, W. M.; BROCKINGTON, D.; DYSON, J.; VIRA, B. Managing Tragedies: Understanding Conflict over Common Pool Resources. Science, n. 302, p. 1915-1916, 2003.

AGORA. Jornal Agora. Política, 14-20 mar. 2008.

AGRICULTORES. Entrevista concedida a Daniel Trento do Nascimento pelos agricultores do bairro Santa Cruz. Içara, SC, 05 jan. 2009.

AXÉ, G. Entrevista concedida a Daniel Trento do Nascimento em Içara. Janeiro de 2009.

BAREMBLITT, G. Compêndio de análise institucional e outras correntes: teoria e prática. Rio de Janeiro: Rosa dos Tempos, 1996.

BOBBIO, N. Dicionário de política. Brasília: UnB, 2004.

CATÂNEO, J. (Presidente da Acarimo). Entrevista concedida a Daniel Trento do Nascimento em 26 jul. 2009. Urussanga, SC.

CIASC - Centro de Informática e Automação de Santa Catarina. Mapas. Disponível em: <http://www.ciasc.gov.br>. Acesso em: 19 mai. 2009.

CORRÊA. J. Proteção ambiental \& atividade minerária. Curitiba: Juruá, 2002.

COSER, L. A. Las funciones del conflicto social. México: FCE, 1961.

DAHRENDORF, R. O conflito social moderno. Rio de Janeiro: Jorge Zahar Editor, 1992.

DURKHEIM, É. Da divisão do trabalho social. 2. ed. São Paulo: Martins Fontes, 1999.

FREITAS, E. B. O movimento popular de Rio Albina (Siderópolis). Monografia (Especialização em Educação Ambiental com ênfase em Gestão e Controle Ambiental) - Escola Agrotécnica Federal de Sombrio, SC. Santa Rosa do Sul, SC, 1998.

GASTALDON, M. C. Entrevista com Murialdo Canto Gastaldon. 17 fev. 2009. Canal Içara. 14 Jun. 2009. Disponível em: $<$ http://www.canalicara.com/blogs/ icaraemdebate/2009/02/ entrevista-com-murialdo-canto-gastaldon.html $>$. Acesso em: 19 jul. 2009.
GOVERNO DO ESTADO DE SANTA CATARINA. Atividades econômicas/Içara. Disponivel em: <http://www.sc.gov. $\mathrm{br} /$ portalturismo/Default.asp? CodMunicipio $=55 \& \mathrm{Pag}=1>$. Acesso em: 08 mai. 2009.

HARDIN, G. The Tragedy of the Commons. Science, n. 162, p. 1243-1248, 1968.

HESS, C.; OSTROM, E. Understanding Knowledge as a Commons: From Theory to Practice. Environment, Cambridge, MA, jul./aug. 2007.

HULSE, R. Um novo olhar sobre o carvão mineral. Jornal Agora. Içara, SC, 7-13 mar. 2008.

IBAMA. Programa Nacional de Capacitação - PNC. Cadernos de formação: como estruturar o Sistema Municipal de Meio Ambiente. Brasília: MMA, v. 2, 2006.

IBGE. Produto Interno Bruto dos Municípios 2002-2005. IBGE. 2007. Disponível em: <www.ibge.gov.br>. Acesso em: 12 out. 2008.

Instituto Brasileiro de Geografia e Estatística, 2006. Disponivel em: <http://www.ibge.gov.br/home/estatistica/ economia/pibmunicipios/2006/tab01.pdf>. Acesso em: 26 jun. 2008.

Pesquisa de Informações Básicas Municipais - MUNIC. Perfil dos municípios brasileiros: meio ambiente, 2008. Rio de Janeiro: IBGE, 2008.

JICA. Estudo de viabilidade da recuperação das áreas mineradas na região sul de Santa Catarina - Relatório JICA. Florianópolis: SDM, 1998.

LEMOS, M. C.; AGRAWAL, A. Environmental Governance. Annual Review of Environment and Resources, v. 31, p. $297-$ 325, 2006.

LINO, R. Superintendente da Fundai em 2008. Entrevista concedida a Daniel Trento do Nascimento. Dez. 2008.

LITTLE, P. Os conflitos socioambientais: um campo de estudo e de ação política. In: BURSZTYN, M. A difícil sustentabilidade: política energética e conflitos ambientais. Rio de Janeiro: Garamond, 2001.

LUIZ, E. L. Análise do EIA-RIMA da mina Esplanada-Içara. Criciúma, fev. 2004.

MARTINEZ-ALIER, J. O ecologismo dos pobres. São Paulo: Contexto, 2007. 
MATIOLA, A. Entrevista concedida a Daniel Trento do Nascimento. Içara, SC, 05 jan. 2009.

; FERNANDEZ, A. W.; VIANA, A.; RAMOS, A.; PIZETTI, W. P.; CASTAGNA, A. S.; D'ESTEFANI, H. J.; VIANA, S. Mídia independente - Contra a mina de carvão, 15 nov. 2003. Disponivel em: $<$ http://www.midiaindependente. org/pt/blue/2003/11/268131.shtml>. Acesso em: 08 mai. 2009.

MOREIRA, L. Mina de carvão em Içara preocupa comunidade local. Ambiente \& Ação, p. 9-11, mai.jun. 2006.

NASCIMENTO, E. P. Os conflitos na sociedade moderna: uma introdução conceitual. In: BURSZTYN, M. A dificil sustentabilidade: política energética e conflitos ambientais. Rio de Janeiro: Garamond, 2001.

NORTH, D. Institutions, Institutional Change and Economic Performance. Cambridge: Cambridge University Press, 1990.

OLSON, M. A lógica da ação coletiva. São Paulo: EDUSP, 1999.

OSTROM, E. Governing the Commons: the Evolution of Institutions for Collective Action. Cambridge: Cambridge University Press, 1990.

. The Challenge of Common-Pool Resources. Environment, Washington, DC, jul./aug. 2008.

PNUD. Atlas do Desenvolvimento Humano. PNUD, 2000. Disponível em: <www.pnud.org.br>. Acesso em: 12 out. 2008.

RBJA - Rede Brasileira de Justiça Ambiental, 2009. Disponível em: $<$ http://www.justicaambiental.org.br/ justicaambiental/ pagina.php?id=135>. Acesso em: 28 jun. 2009.
REDIVO, R. Gerente de Meio Ambiente da Empresa Rio Deserto. Entrevista concedida a Daniel Trento do Nascimento. Criciúma, SC, 18 jan. 2009.

REUS, W. Canal Içara, 17 Fev. 2009. Disponivel em: <http:/ www.canalicara.com/blogs/icaraemdebate/2009/02/entrevista-com-walterney-angelo-reus.html>. Acesso em: 15 jun. 2009.

RIBEIRO, J. T. M.; FERREIRA, G. C. Mineração subterrânea de carvão $x$ comunidade no seu entorno: um exemplo de Santa Catarina. REM, v. 60, n. 3, p. 459-464, 2007.

RIO DESERTO. Empresa. Disponivel em: <http://www.riodeserto.com.br>. Acesso em: 10 mai. 2009.

RÖLING, B. V. A. The role of law in conflict resolution. In: REUCK, A.; KNIGHT, J. Conflict in Society. London: J \& A Churchill, 1966.

SANTOS, J. V. Um olhar socioambiental da História: a trajetória do movimento ambientalista e seus conflitos com a atividade carbonífera no sul de Santa Catarina (1980-2008). Dissertação (Mestrado) - Programa de Pós-graduação em História da UFSC. Florianópolis: UFSC, 2008.

SIMMEL, G. Conflict and the web of Group-Affiliations. Toronto: Collier-Macmillan, 1969

SOS MATA ATLÂNTICA. Atlas dos remanescentes florestais da Mata Atlântica, 2005. Disponivel em: $<\mathrm{http}: / /$ mapas.sosma. org.br/>. Acesso em: 09 mai. 2009.

THEODORO, S. H. Mediação de conflitos socioambientais. Rio de Janeiro: Garamond, 2005.

VIANNA, J. N. D. S. Energia e meio ambiente no Brasil. In: BURSZTYN, M. A dificil sustentabilidade: política energética e conflitos ambientais. Rio de Janeiro: Garamond, 2001.

Recebido em setembro de 2010.

Aceito em novembro de 2010.

Publicado em dezembro de 2010. 